\title{
Binding and Signaling Studies Disclose a Potential Allosteric Site for Cannabidiol in Cannabinoid $\mathbf{C B}_{2}$ Receptors
}

OPEN ACCESS

Edited by:

Claudio M. Costa-Neto,

University of São Paulo, Brazil

Reviewed by:

François Noël,

Federal University of Rio de Janeiro,

Brazil

J. Robert David Lane,

Monash University, Australia

*Correspondence:

Eva Martínez-Pinilla

martinezpinillaeva@gmail.com

${ }^{\dagger}$ These authors have contributed equally to this work.

Specialty section:

This article was submitted to Experimental Pharmacology and Drug

Discovery,

a section of the journal

Frontiers in Pharmacology

Received: 29 June 2017 Accepted: 02 October 2017

Published: 23 October 2017

Citation:

Martínez-Pinilla E, Varani K, Reyes-Resina I, Angelats $E$

Vincenzi F, Ferreiro-Vera $C$, Oyarzabal J, Canela El, Lanciego JL, Nadal X, Navarro G, Borea PA and

Franco R (2017) Binding and Signaling Studies Disclose

a Potential Allosteric Site

for Cannabidiol in Cannabinoid $C B_{2}$ Receptors. Front. Pharmacol. 8:744.

doi: 10.3389/fphar.2017.00744
Eva Martínez-Pinilla ${ }^{\text {* }}$, Katia Varani ${ }^{2+}$, Irene Reyes-Resina ${ }^{3,4 \dagger}$, Edgar Angelats ${ }^{3,4}$, Fabrizio Vincenzi ${ }^{2}$, Carlos Ferreiro-Vera ${ }^{5}$, Julen Oyarzabal ${ }^{6}$, Enric I. Canela ${ }^{3,4}$, José L. Lanciego ${ }^{7}$, Xavier Nadal ${ }^{5}$, Gemma Navarro ${ }^{3,4,8}$, Pier Andrea Borea ${ }^{2}$ and Rafael Franco ${ }^{3,4}$

1 Instituto de Neurociencias del Principado de Asturias, Departamento de Morfología y Biología Celular, Facultad de Medicina, Universidad de Oviedo, Asturias, Spain, ${ }^{2}$ Pharmacology Institute, Department of Medical Sciences, University of Ferrara, Ferrara, Italy, ${ }^{3}$ Molecular Neurobiology Laboratory, Department of Biochemistry and Molecular Biomedicine, University of Barcelona, Barcelona, Spain, ${ }^{4}$ Centro de Investigación Biomédica en Red Enfermedades Neurodegenerativas, Instituto de Salud Carlos III, Madrid, Spain, ${ }^{5}$ Phytoplant Research S.L., Córdoba, Spain, ${ }^{6}$ Small Molecule Discovery Platform, Molecular Therapeutics Program, Center for Applied Medical Research, University of Navarra, Pamplona, Spain, ${ }^{7}$ Neuroscience Department, Center for Applied Medical Research, University of Navarra, Pamplona, Spain, ${ }^{8}$ Department of Biochemistry and Physiology, Faculty of Pharmacy, University of Barcelona, Barcelona, Spain

The mechanism of action of cannabidiol (CBD), the main non-psychotropic component of Cannabis sativa L., is not completely understood. First assumed that the compound was acting via cannabinoid $\mathrm{CB}_{2}$ receptors $\left(\mathrm{CB}_{2} \mathrm{Rs}\right)$ it is now suggested that it interacts with non-cannabinoid G-protein-coupled receptors (GPCRs); however, CBD does not bind with high affinity to the orthosteric site of any GPCR. To search for alternative explanations, we tested $\mathrm{CBD}$ as a potential allosteric ligand of $\mathrm{CB}_{2} \mathrm{R}$. Radioligand and non-radioactive homogeneous binding, intracellular CAMP determination and ERK1/2 phosphorylation assays were undertaken in heterologous systems expressing the human version of $\mathrm{CB}_{2} \mathrm{R}$. Using membrane preparations from $\mathrm{CB}_{2} \mathrm{R}$-expressing HEK293T (human embryonic kidney 293T) cells, we confirmed that CBD does not bind with high affinity to the orthosteric site of the human $\mathrm{CB}_{2} \mathrm{R}$ where the synthetic cannabinoid, $\left[{ }^{3} \mathrm{H}\right]-$ WIN 55,212-2, binds. CBD was, however, able to produce minor but consistent reduction in the homogeneous binding assays in living cells using the fluorophore-conjugated $\mathrm{CB}_{2} \mathrm{R}$-selective compound, $\mathrm{CM}-157$. The effect on binding to $\mathrm{CB}_{2} \mathrm{R}$-expressing living cells was different to that exerted by the orthosteric antagonist, SR144528, which decreased the maximum binding without changing the $K_{\mathrm{D}}$. CBD at nanomolar concentrations was also able to significantly reduce the effect of the selective $\mathrm{CB}_{2} \mathrm{R}$ agonist, JWH133, on forskolin-induced intracellular cAMP levels and on activation of the MAP kinase pathway. These results may help to understand CBD mode of action and may serve to revisit its therapeutic possibilities.

Keywords: endocannabinoid, allosterism, G-protein-coupled receptor, phytocannabinoids, SR144528, irreversible, TR-FRET

Abbreviations: $\mathrm{AEA}$, anandamide; 2-AG, 2-arachidonyl glycerol; $\mathrm{CBD}$, cannabidiol; $\mathrm{CB}_{1} \mathrm{R}$, cannabinoid receptor subtype 1; $\mathrm{CB}_{2} \mathrm{R}$, cannabinoid receptor subtype 2; CNS, central nervous system; GPCR, G-protein-coupled-receptor; HTRF, homogenous time-resolved fluorescence resonance energy transfer; $\Delta^{9}$-THC, $\Delta^{9}$-tetrahydrocannabinol; TR-FRET, timeresolved fluorescence resonance energy transfer. 


\section{INTRODUCTION}

The endocannabinoid system consists of two compounds with amphipathic structure, 2-arachidonyl glycerol (2-AG) and anandamide (AEA), the enzymes that produce and degrade them, and two cannabinoid, $\mathrm{CB}_{1}$ and $\mathrm{CB}_{2}$, receptors (see $\mathrm{Lu}$ and MacKie, 2016 and references therein). Recent evidence presents the endocannabinoid system as one of the most relevant in mammals for homeostatic control of energy expenditure and temperature, and for regulating innate and acquired immunity and neural transmission. Cannabinoid receptors belong to the superfamily of G-protein-coupled receptors (GPCRs) and are reportedly coupled to the heterotrimeric $G_{i}$ protein ${ }^{1}$, i.e., their activation leads to a decrease in the intracellular level of a second messenger, cAMP. Although $\mathrm{CB}_{1}$ receptors $\left(\mathrm{CB}_{1} \mathrm{Rs}\right)$ are mainly located in neurons of the central nervous system (CNS), their expression in glia has been described (Stella, 2010; Bilkei-Gorzo, 2012). In fact, $\mathrm{CB}_{1} \mathrm{Rs}$ are considered to be the most abundant GPCRs in the CNS and the targets of the $\Delta^{9}$-tetrahydrocannabinol $\left(\Delta^{9}\right.$-THC), the main psychotropic component of Cannabis sativa $\mathrm{L} . \mathrm{CB}_{2}$ receptor $\left(\mathrm{CB}_{2} \mathrm{R}\right)$, which soon after its identification was considered a prototypic peripheral receptor, is also expressed in the CNS, both in glia (Zhang et al., 2003; Cabral and Marciano-Cabral, 2005; Fernández-Ruiz et al., 2007) and neurons of some specific brain regions such as cerebellum or globus pallidus (Lanciego et al., 2011; Sierra et al., 2015). Heteromerization of $\mathrm{CB}_{1} \mathrm{R} / \mathrm{CB}_{2} \mathrm{R}$ in the brain is a well-accepted phenomenon that further diversifies the physiological actions of endo- and exogenous cannabinoids (Callén et al., 2012; Sierra et al., 2015). Although physiological relevance of this heteromer expression is not fully understood, evidence suggests potential in CNS-related drug discovery.

Apart from heteromerization, drug discovery efforts for cannabinoid receptors also involve the use of allosteric cannabinoid ligands. Whereas cannabinoids interact with the orthosteric receptor site, allosteric modulators bind to a topographically distinct binding site modifying receptor conformation and leading to novel properties and modes of action (Conn et al., 2009). In fact, allosteric modulators can impact on the affinity of the orthosteric binding pocket and also in the intracellular signaling responses, in either a positive or negative direction. To date, a number of allosteric cannabinoid receptor modulators have been reported for $\mathrm{CB}_{1} \mathrm{R}$, e.g., lipoxin A4, ORG27569, PSNCBAM-1 or cannabidiol (CBD) (Pamplona et al., 2012; Laprairie et al., 2015; Morales et al., 2016).

$\mathrm{CBD}$, the main non-psychoactive phytocannabinoid, exerts a wide range of cellular effects through the endocannabinoid system, as was indicated in a systematic review in 2015 (McPartland et al., 2015). However, its mode of action is far from being understood. In some in vitro assays, $\mathrm{CBD}$ action has been linked to $\mathrm{CB}_{2} \mathrm{Rs}$ activation because some in vivo effects were blocked by the administration of a $\mathrm{CB}_{2} \mathrm{R}$ antagonist. Thus, Ignatowska-Jankowska et al. (2011), using AM630 as antagonist, reported that the weight gain-reducing effect of CBD apparently

${ }^{1}$ www.guidetopharmacology.org involved $\mathrm{CB}_{2}$ Rs. In addition, the well-substantiated protective role of $\mathrm{CBD}$ in newborn hypoxia-ischemia correlates with $\mathrm{CB}_{2} \mathrm{R}$ expression (Castillo et al., 2007; Alvarez et al., 2008; Lafuente et al., 2011; Pazos et al., 2013). In other in vitro assays, CBD was shown as a high potency antagonist of $\mathrm{CB}_{2} \mathrm{R}$ expressed in CHO cells (Thomas et al., 2009). Nevertheless, radioligand and/or GTPgammaS binding assays indicate that the compound does not bind with high affinity to either rat or human $\mathrm{CB}_{2} \mathrm{Rs}$ (Hanus et al., 2005; Pertwee, 2008; McPartland et al., 2009). At present, the idea that $\mathrm{CBD}$ actions are mediated by binding to serotonin 5$\mathrm{HT}_{1 \mathrm{~A}}$ receptors is favored. For instance, CBD affords protection against oxygen-glucose deprivation in a model of the blood-brain barrier by a mechanism involving $5-\mathrm{HT}_{1 \mathrm{~A}}$ and $\mathrm{PPAR} \gamma$ receptors (Hind et al., 2016). Further behavioral studies also suggest that $\mathrm{CBD}$ may act via $5-\mathrm{HT}_{1 \mathrm{~A}}$ receptors (Russo et al., 2005; Alves et al., 2010; Magen et al., 2010; Rock et al., 2012; Espejo-Porras et al., 2013; Sartim et al., 2016). Such assumption is intriguing as the reported affinity of CBD binding to these serotonin receptors does not lie within the nanomolar high affinity range (Russo et al., 2005). More recently, some authors open new avenues in the therapeutic use of this phytocannabinoid. Thus, they seem to demonstrate that CBD was able to reduce the effect of 2-AG and $\Delta^{9}$-THC on $\mathrm{CB}_{1} \mathrm{R}$ internalization and PLC $\beta 3$ and ERK1/2 phosphorylation, proposing that $\mathrm{CBD}$ may act as a negative allosteric modulator of these receptors (Laprairie et al., 2015).

The aim of this work was to search for the possibility that $\mathrm{CBD}$ acts as an allosteric ligand of $\mathrm{CB}_{2} \mathrm{R}$ by checking whether it is able to modulate the binding and functional effect of $\mathrm{CB}_{2} \mathrm{R}$ agonists.

\section{MATERIALS AND METHODS}

\section{Materials and Reagents}

For radioligand binding assays, $\left[{ }^{3} \mathrm{H}\right]-(\mathrm{R})-(+)-[2,3$-dihydro-5 -methyl-3-(4-morpholinyl methyl)pyrrolo[1,2,3-de]-1,4-benzoxazin-6-yl]-1-naphthalenylmethanone $\left(\left[{ }^{3} \mathrm{H}\right]-\right.$ WIN $\left.55,212-2\right)$ was purchased from PerkinElmer (Wellesley, MA, United States). CBD, WIN 55,212-2 mesylate and SR144528 were obtained from Tocris Bioscience (Bristol, United Kingdom). THC was obtained from THC Pharm (Frankfurt, Germany).

For non-radioactive binding assays, the Tag-lite labeling medium (TLB) was obtained from Cisbio Bioassays (LABMED, Cisbio Assays, Codolet, France). The Tb derivative of O6-benzylguanine was synthesized by Cisbio Bioassays and is commercialized as SNAP-Lumi4-Tb (SSNPTBC, Cisbio Assays, Codolet, France). $\mathrm{CB}_{2} \mathrm{R}$ agonist, 3-[[4-[2-tert-butyl-1-(tetrahydropyran-4-ylmethyl)benzimidazol-5-yl]sulfonyl-2-pyridyl]oxy]propan-1-amine (CM-157), conjugated to red-naltrexone fluorescent probe (red $\mathrm{CB}_{2} \mathrm{R}$ ligand) was developed by Cisbio Bioassays. The unlabeled compound was synthesized as described in Martínez-Pinilla et al. (2016) based on the information given in the WO2008003665 patent and in Verbist et al. (2008). Stock solutions were prepared in DMSO. Aliquots of these stock solutions were kept frozen at $-20^{\circ} \mathrm{C}$ until use. The plasmid encoding for the SNAP-tagged human $\mathrm{CB}_{2} \mathrm{R}$ used 
for transient transfection was obtained from Cisbio Bioassays (PSNAP-CB2, Cisbio Assays, Codolet, France). The white opaque 384-well plates were obtained from PerkinElmer (Wellesley, MA, United States).

\section{Radioligand Binding Assays Cell Culture and Membrane Preparation}

$\mathrm{CHO}$ cells stably expressing human $\mathrm{CB}_{2} \mathrm{R}\left(\mathrm{CHO}-\mathrm{CB}_{2} \mathrm{R}\right)$ (PerkinElmer, United States) were grown adherently and maintained in Ham's F12 medium containing 10\% heatinactivated fetal bovine serum (FBS), 100 units $/ \mathrm{mL}$ penicillin/streptomycin and $0.4 \mathrm{mg} / \mathrm{mL}$ geneticin $(\mathrm{G} 418)$ at $37^{\circ} \mathrm{C}$ in $5 \% \mathrm{CO}_{2}$ humid atmosphere.

For membrane isolation, culture medium was removed and cells were washed with phosphate-buffered saline (PBS) and scraped off in ice-cold hypotonic buffer ( $5 \mathrm{mM}$ Tris-HCl, $2 \mathrm{mM}$ EDTA, pH 7.4). The cell suspension was homogenized with a Polytron and then centrifuged for $30 \mathrm{~min}$ at $40,000 \times \mathrm{g}$. The membrane pellet was suspended in $50 \mathrm{mM}$ Tris- $\mathrm{HCl}$ buffer $(\mathrm{pH}$ 7.4) containing $1 \mathrm{mM}$ EDTA, $5 \mathrm{mM} \mathrm{MgCl} 2,0.5 \mathrm{mg} / \mathrm{mL}$ bovine serum albumin (BSA).

\section{Saturation Binding Experiments}

$\left[{ }^{3} \mathrm{H}\right]$-WIN 55,212-2 saturation binding experiments (specific activity $48 \mathrm{Ci} / \mathrm{mmol}$, PerkinElmer) were performed incubating different concentrations of the radioligand $(0.2-40 \mathrm{nM})$ in binding buffer (50 mM Tris- $\mathrm{HCl}, \mathrm{pH}$ 7.4, 1 mM EDTA, $5 \mathrm{mM}$ $\mathrm{MgCl}_{2}$ ) with membranes from $\mathrm{CHO}$ cells stably expressing the human $\mathrm{CB}_{2} \mathrm{R}\left(10 \mu \mathrm{g}\right.$ per sample) at $30^{\circ} \mathrm{C}$. Non-specific binding was determined in the presence of $1 \mu \mathrm{M}$ WIN 55,212-2. At the end of the incubation period $(60 \mathrm{~min})$ bound and free radioactivity were separated in a Brandel cell harvester (Brandel Instruments) by filtering the assay mixture through Whatman GF/B glass fiber filters. The filter-bound radioactivity was counted using a Packard Tri Carb 2810 TR scintillation counter (PerkinElmer, Wellesley, MA, United States).

\section{Association Binding Experiments}

Association binding experiments for $\left[{ }^{3} \mathrm{H}\right]$-WIN 55,212-2 were performed incubating three different concentrations $(0.8,1.6$, and $3.2 \mathrm{nM}$ ) of the radioligand in binding buffer $(50 \mathrm{mM}$ Tris- $\mathrm{HCl}$, $\mathrm{pH} 7.4,1 \mathrm{mM}$ EDTA, $5 \mathrm{mM} \mathrm{MgCl}_{2}$ ) with human $\mathrm{CHO}-\mathrm{CB}_{2} \mathrm{R}$ cell membranes at $30^{\circ} \mathrm{C}$. Non-specific binding was determined in the presence of $1 \mu \mathrm{M}$ WIN 55,212-2. Free and bound radioligand were separated through filtration at multiple time points (from 1 to $50 \mathrm{~min}$ ) to construct association kinetic curves.

\section{Dissociation Binding Experiments}

The dissociation rate of $\left[{ }^{3} \mathrm{H}\right]-$ WIN 55,212-2 was determined by allowing $3 \mathrm{nM}$ radioligand to reach equilibrium with human $\mathrm{CHO}-\mathrm{CB}_{2} \mathrm{R}$ cell membranes at $30^{\circ} \mathrm{C}$ for $60 \mathrm{~min}$. To start dissociation, WIN 55,212-2 (10 $\mu \mathrm{M}$ final concentration) was added in order to occupy binding sites as they became available, thereby preventing re-association. The amount of radioactivity that remained bound to the receptor was determined by filtration harvesting and scintillation counting at different time points (from 0 to $50 \mathrm{~min}$ ).

\section{Competition Binding Experiments}

Competition binding experiments were performed incubating $3 \mathrm{nM}\left[{ }^{3} \mathrm{H}\right]$-WIN 55,212-2 and different concentrations of the tested compounds with membranes obtained from $\mathrm{CHO}-\mathrm{CB}_{2} \mathrm{R}$ cells (10 $\mu \mathrm{g}$ protein per sample) for $60 \mathrm{~min}$ at $30^{\circ} \mathrm{C}$. Nonspecific binding was determined in the presence of $1 \mu \mathrm{M}$ WIN $55,212-2$. Bound and free radioactivity were separated by filtering the assay mixture through Whatman GF/B glass fiber filters using a Brandel cell harvester. The filter-bound radioactivity was counted using a Packard Tri Carb 2810 TR scintillation counter (PerkinElmer).

\section{Non-radioligand Binding Assays Cell Line Cultures and Transfection}

Human embryonic kidney 293T (HEK-293T) cells were grown in DMEM supplemented with $2 \mathrm{mM}$ L-glutamine, $1 \mathrm{mM}$ sodium pyruvate, 100 units/mL penicillin/streptomycin, and 5\% (v/v) FBS (all supplements were from Invitrogen, Paisley, Scotland, United Kingdom). Cells were maintained at $37^{\circ} \mathrm{C}$ in a humidified atmosphere of $5 \% \mathrm{CO}_{2}$ and were passaged, with enzyme-free cell dissociation buffer (13151-014, Gibco ${ }^{\circledR}$, Thermo Fisher Scientific, Waltham, MA, United States), when they were 80-90\% confluent, i.e., approximately twice a week.

For fluorescent ligand-binding assays, HEK-293T cells growing in $25-\mathrm{cm}^{2}$ flasks were transiently transfected with the SNAP- $\mathrm{CB}_{2} \mathrm{R}$ plasmid cloned in pcDNA3.1 by the Lipofectamine 2000 method (11668-019, Invitrogen, Thermo Fisher Scientific, Waltham, MA, United States). When reaching 60\% confluence, cell medium was removed and replaced by $4 \mathrm{~mL}$ of fresh medium. In parallel, a transfection mix containing $8 \mu \mathrm{g}$ of plasmid, $20 \mu \mathrm{L}$ of Lipofectamine 2000, and $1 \mathrm{~mL}$ of Opti-MEM without serum (51985-026, Gibco ${ }^{\circledR}$, Thermo Fisher Scientific, Waltham, MA, United States) final volume was incubated for $20 \mathrm{~min}$ at room temperature prior to being added on cells. The transfected-cell culture flask was incubated at $37^{\circ} \mathrm{C}$ under $5 \%$ $\mathrm{CO}_{2}$ for $24 \mathrm{~h}$.

\section{Labeling of Cells Expressing SNAP-Tagged $\mathrm{CB}_{2} \mathrm{R}$}

Cell culture medium was removed from the $25-\mathrm{cm}^{2}$ flask and $100 \mathrm{nM}$ SNAP-Lumi4-Tb, previously diluted in $3 \mathrm{~mL}$ of TLB $1 \times$, was added to the flask and incubated for $1 \mathrm{~h}$ at $37^{\circ} \mathrm{C}$ under $5 \% \mathrm{CO}_{2}$ atmosphere in a cell incubator. After that, cells were washed four times with $2 \mathrm{~mL}$ of TLB $1 \times$ to remove the excess of SNAP-Lumi4-Tb, detached with enzyme-free cell dissociation buffer, centrifuged $5 \mathrm{~min}$ at 1,500 rpm and collected in $1 \mathrm{~mL}$ of TLB $1 \times$. Tag-lite-based binding assays were performed $24 \mathrm{~h}$ after transfection. Densities from 2,500 to 3,000 cells per well were used to carry out binding assays in suspension in white opaque 384-well plates.

\section{Competition and Saturation Binding Assays}

For competition binding assay, red $\mathrm{CB}_{2} \mathrm{R}$ ligand (labeled CM157) and CBD were diluted in TLB $1 \times$. HEK-293T cells transiently expressing Tb-labeled SNAP- $\mathrm{CB}_{2} \mathrm{R}$ were incubated with $100 \mathrm{nM}$ red $\mathrm{CB}_{2} \mathrm{R}$ ligand, in the presence of increasing concentrations ( $0-10 \mu \mathrm{M}$ range) of CBD. In plates containing $10 \mu \mathrm{L}$ of labeled cells, $5 \mu \mathrm{L}$ of TLB $1 \times$ or $5 \mu \mathrm{L}$ of CBD was added 


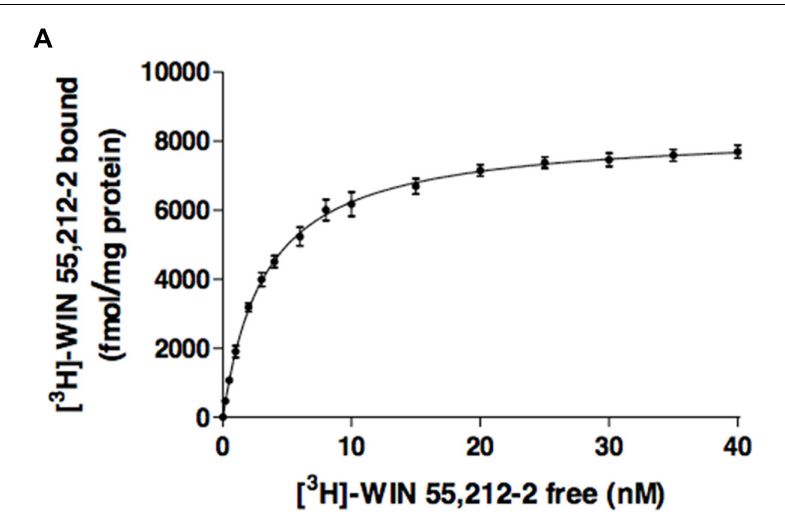

B

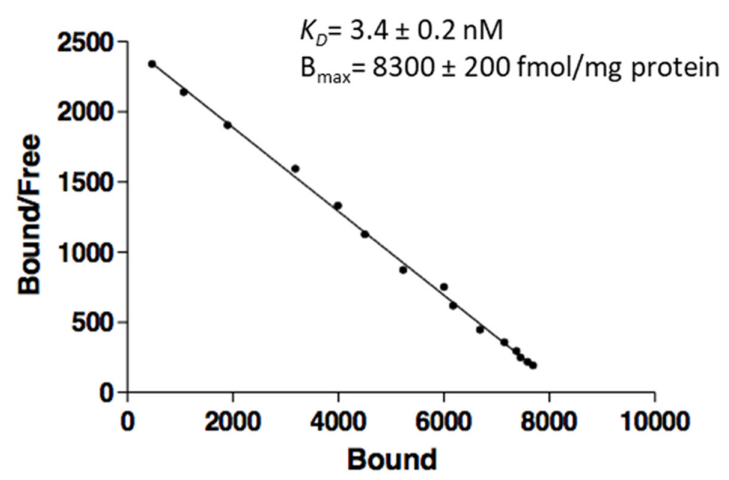

FIGURE 1 | Saturation curves from radioligand binding. Saturation curve (A) and relative Scatchard plot (B) of $\left[{ }^{3} \mathrm{H}\right]-\mathrm{WIN} 55,212-2$ binding on membranes from $\mathrm{CHO}$ cells stably expressing human $\mathrm{CB}_{2} \mathrm{R}$. Data are expressed as the mean \pm SEM of three independent experiments performed in duplicate.

prior to the addition of $5 \mu \mathrm{L}$ of fluorescent ligand. Plates were then incubated for at least $2 \mathrm{~h}$ at room temperature before signal detection.

Saturation binding experiments were performed by incubating HEK-293T cells transiently expressing Tb-labeled SNAP-CB ${ }_{2} \mathrm{R}$ with increasing concentrations of the red $\mathrm{CB}_{2} \mathrm{R}$ ligand (range, 0-300 nM final) in TLB $1 \times$. For each concentration, non-specific binding was determined by adding $100 \mu \mathrm{M}$ unlabeled $\mathrm{CB}_{2} \mathrm{R}$ ligand. In the plates containing $10 \mu \mathrm{L}$ labeled cells, $5 \mu \mathrm{L}$ of $100 \mu \mathrm{M}$ unlabeled $\mathrm{CB}_{2} \mathrm{R}$ ligand or TLB $1 \times$ was added, followed by the addition of $5 \mu \mathrm{L}$ of increasing concentrations of the red $\mathrm{CB}_{2} \mathrm{R}$ ligand. Plates were incubated for $2 \mathrm{~h}$ at room temperature before signal reading.

Signal was detected using an EnVision microplate reader (PerkinElmer, Waltham, MA, United States) equipped with a FRET optic module allowing donor excitation at $337 \mathrm{~nm}$ and signal collection at both 665 and $620 \mathrm{~nm}$. A frequency of 10 flashes/well was selected for the xenon flash lamp excitation. The signal was collected at both 665 and $620 \mathrm{~nm}$ using the following time-resolved settings: delay, $150 \mu \mathrm{s}$; integration time, $500 \mu \mathrm{s}$. HTRF ratios were obtained by dividing the acceptor signal $(665 \mathrm{~nm})$ by the donor signal $(620 \mathrm{~nm})$ and multiplying this value by 10,000 . The 10,000-multiplying factor is used solely for the purpose of easier data handling.

\section{Data Analysis}

Data were then analyzed using Prism 6 (GraphPad Software, Inc., San Diego, CA, United States). $K_{\mathrm{D}}$ values were obtained from saturation curves of the specific binding. Specific binding was determined by subtracting the non-specific HTRF ratio from the total HTRF ratio. $K_{\mathrm{D}}$ and $B_{\max }$ values in saturations experiments were calculated assuming one binding site in monomeric receptor. Unlike in radioligand binding assays, $B_{\max }$ values obtained from HTRF data do not reflect absolute values of receptor binding sites; they are, however, useful for comparison purposes. Finally, $K_{\mathrm{i}}$ values were determined according to the Cheng and Prusoff equation (Cheng, 2001). Signal-to-background (S/B ratio) calculations were performed by dividing the mean of the maximum value $\left(\mu_{\max }\right)$ by that of the minimum value $\left(\mu_{\min }\right)$ obtained from the sigmoid fits.

\section{CAMP Determination}

Two hours before initiating the experiment, growth medium was replaced by serum-free DMEM. Then, HEK-293T cells transiently expressing $\mathrm{CB}_{2} \mathrm{R}$ or GPR55 were detached and
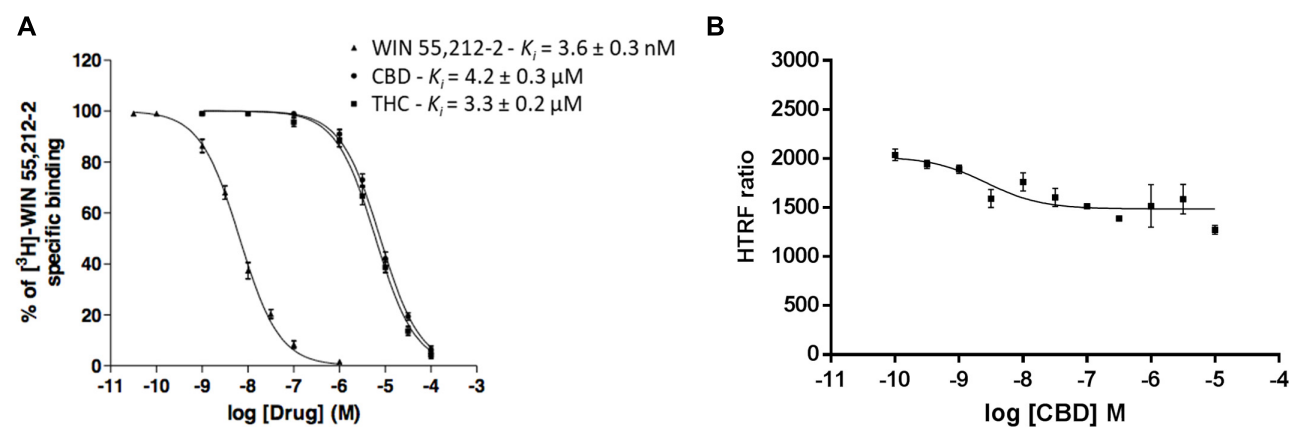

FIGURE 2 | Competition curves in radioligand- and HTRF-based assays. (A) Competition curves of specific $3 \mathrm{nM}\left[{ }^{3} \mathrm{H}\right]-\mathrm{WIN} 55,212-2$ binding by unlabeled (0-10 $\mu \mathrm{M})$ WIN 55,212-2, CBD and THC. (B) Competition curve of specific binding of $100 \mathrm{nM}$ red $\mathrm{CB}_{2} \mathrm{R}$ ligand with increasing concentrations of CBD (0-10 $\left.\mu \mathrm{M}\right)$ measured by HTRF. Data represent the mean \pm SEM of a representative experiment $(n=4)$. HTRF ratio $=(665 \mathrm{~nm}$ acceptor signal/620 $\mathrm{nm}$ donor signal $\times 10,000$. 

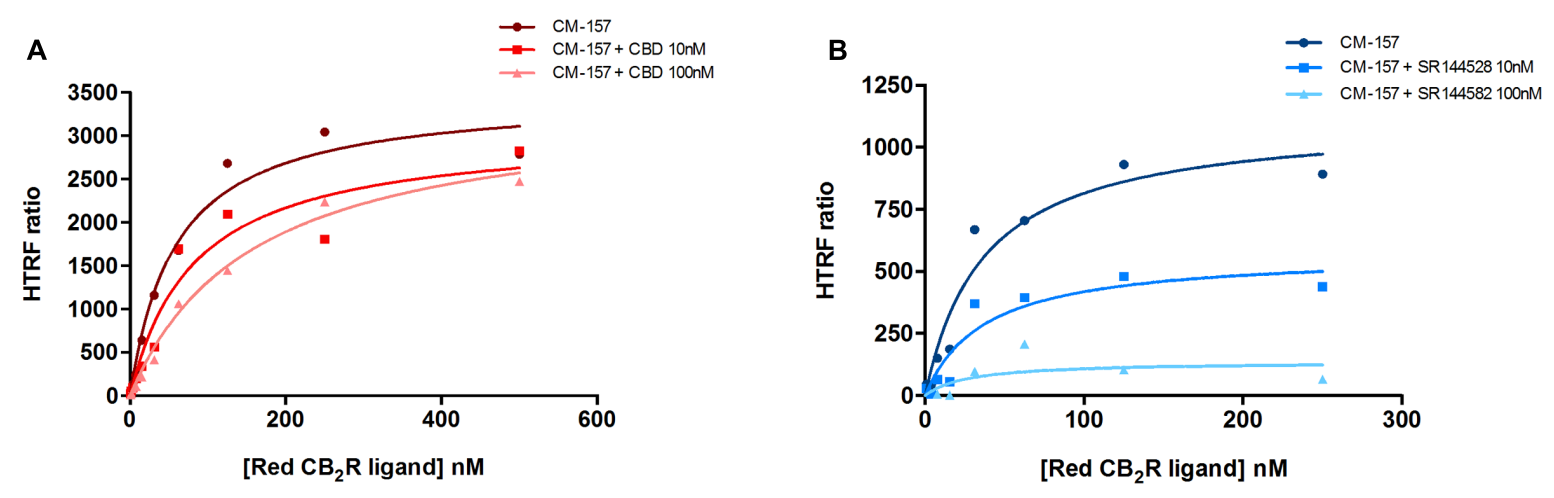

FIGURE 3 | Saturation curves measured by HTRF. Saturation binding experiments of fluorescent $\mathrm{CB}_{2} \mathrm{R}$ ligand (CM-157) in HEK-293T cells transiently transfected with SNAP-CB 2 R in the absence or presence of $10 \mathrm{nM}$ (squares) or $100 \mathrm{nM}$ (triangles) CBD (A), or in the absence or presence of $10 \mathrm{nM}$ (squares) or $100 \mathrm{nM}$ (triangles) SR144528 (B). Specific binding signals were calculated by subtracting the non-specific signal determined in the presence of $100 \mu \mathrm{M}$ unlabeled $\mathrm{CB}_{2} \mathrm{R}$ ligand. Data represent the mean \pm SEM of a representative experiment $(n=4)$. HTRF ratio $=(665 \mathrm{~nm}$ acceptor signal/620 nm donor signal $) \times 10,000$.

TABLE 1| Red $\mathrm{CB}_{2} \mathrm{R}$ ligand (CM-157) binding parameters, in the absence and presence of CBD. Data represent the mean \pm SEM of five independent experiments performed in quadruplicate.

\begin{tabular}{lcc}
\hline Condition & $\boldsymbol{K}_{\mathbf{D}}$ (nM) & $\boldsymbol{B}_{\max }(\mathbf{R U})^{\mathbf{a}, \mathbf{b}}$ \\
\hline Red $\mathrm{CB}_{2}$ R ligand & $60 \pm 10$ & $3,480 \pm 210$ \\
Red $\mathrm{CB}_{2}$ R ligand + $10 \mathrm{nM}$ CBD & $82 \pm 28$ & $3,060 \pm 360$ \\
Red $\mathrm{CB}_{2}$ R ligand + $100 \mathrm{nM}$ CBD & $160 \pm 20^{*}$ & $3,380 \pm 210$ \\
\hline
\end{tabular}

${ }^{\mathrm{a}} \mathrm{RU}$, relative unit. ${ }^{\mathrm{b}} \mathrm{B}_{\max }$ parameter does not indicate the actual level of binding sites, but it may be used for comparative purposes. *Significant differences analyzed by one-way ANOVA and Bonferroni's multiple comparison post hoc tests ${ }^{*} p<0.05$ versus absence of $\left.C B D\right)$.

resuspended in growing medium containing $50 \mu \mathrm{M}$ zardaverine and plated in 384-well microplates (2,500 cells/well), pretreated (15 $\mathrm{min}$ ) with the corresponding antagonists-or vehicle-and stimulated with agonists ( $15 \mathrm{~min}$ ) before adding $0.5 \mu \mathrm{M}$ forskolin or vehicle. Readings were performed after $15 \mathrm{~min}$ of incubation at $25^{\circ} \mathrm{C}$. HTRF measures were performed using the Lance Ultra cAMP kit (PerkinElmer, Waltham, MA, United States). Fluorescence at $665 \mathrm{~nm}$ was analyzed on a PHERAstar Flagship microplate reader equipped with an HTRF optical module (BMG Lab Technologies, Offenburg, Germany).

\section{ERK1/2 Phosphorylation}

To determine ERK1/2 phosphorylation, 40,000 HEK-293T- $\mathrm{CB}_{2} \mathrm{R}$ cells/well were plated in transparent Deltalab 96-well microplates and kept at the incubator for $24 \mathrm{~h}$. Two to four hours before the experiment, the medium was replaced by serum-free DMEM. Then, cells were treated with $100 \mathrm{nM}$ JWH133 and increasing concentrations of $\mathrm{CBD}$ in serum-free medium at $25^{\circ} \mathrm{C}$ for 7 min. Cells were then washed twice with cold PBS before addition of lysis buffer (20 min treatment). Ten microliters of each supernatant were placed in white ProxiPlate 384-well microplates and ERK1/2 phosphorylation was determined using AlphaScreen ${ }^{\circledR}$ SureFire ${ }^{\circledR}$ kit (PerkinElmer) following the instructions of the supplier and using an EnSpire ${ }^{\circledR}$ Multimode Plate Reader (PerkinElmer, Waltham, MA, United States).

\section{Statistical Analysis}

The data in graphs are the mean \pm SEM. Statistical analysis was performed with SPSS 18.0 software. The test of KolmogorovSmirnov with the correction of Lilliefors was used to evaluate normal distribution and the test of Levene to evaluate the homogeneity of variance. Significance was analyzed by oneway ANOVA, followed by Bonferroni's multiple comparison post hoc test. Significant differences were considered when $p<0.05$.

\section{RESULTS}

\section{Radioligand-Based Assays of Agonist Binding to Human $\mathrm{CB}_{2} \mathrm{R}$ Expressed in Isolated Membranes}

The effect of $\mathrm{CBD}$ on agonist binding to $\mathrm{CB}_{2} \mathrm{R}$ was first tested using a classical radioligand-binding assay and membranes isolated from $\mathrm{CHO}$ cells stably expressing human $\mathrm{CB}_{2} \mathrm{R}$ and incubated with $\left[{ }^{3} \mathrm{H}\right]$-WIN 55,212-2. Data obtained from binding isotherms using increasing WIN 55,212-2 concentrations lead to a monophasic saturation curve with a $K_{\mathrm{D}}$ value of $3.4 \pm 0.2 \mathrm{nM}$ (Figures 1A,B), which fits with the values reported in the literature (McPartland et al., 2009). Kinetic experiments of association of $\left[{ }^{3} \mathrm{H}\right]-W I N$ 55,212-2 (Supplementary Figure 1A) and its dissociation by excess unlabeled WIN 55,212-2 (Supplementary Figure 1B) showed $k_{\text {on }}$ and $k_{\text {off }}$ values whose quotient provides an equilibrium constant that is in agreement with the $K_{\mathrm{D}}$ value calculated from saturation data.

\section{Competition and Saturation Assays in the Presence of CBD}

Competition of $3 \mathrm{nM}\left[{ }^{3} \mathrm{H}\right]-$ WIN 55,212-2 with increasing concentrations of the "cold" compound led to a $K_{\mathrm{i}}$ value of $3.6 \pm 0.3 \mathrm{nM}$, well in agreement with the $K_{\mathrm{D}}$ (Figure 2A). The $K_{\mathrm{i}}$ value, when $\mathrm{CBD}$ was used as competitor, was in the 


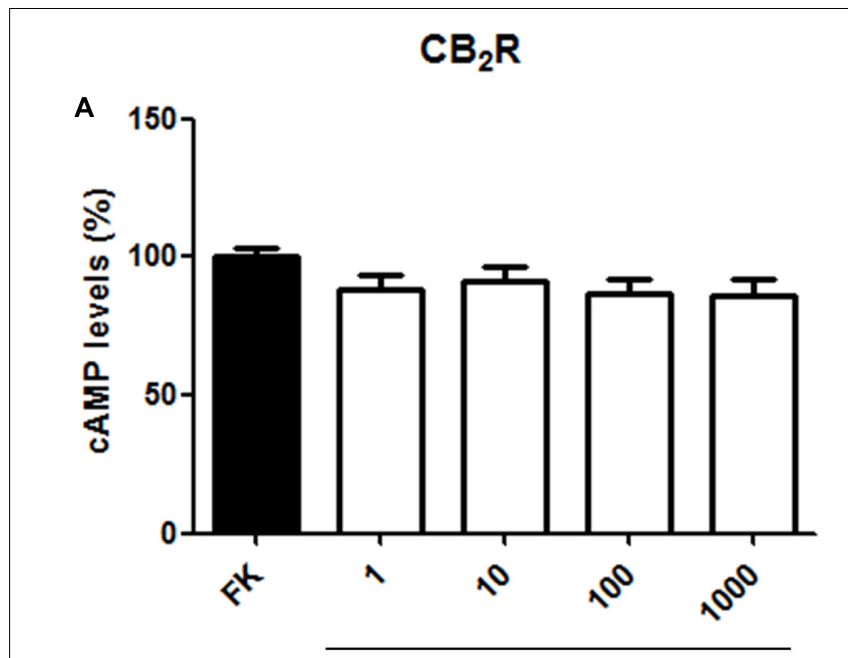

$[\mathrm{CBD}] \mathrm{nM}$

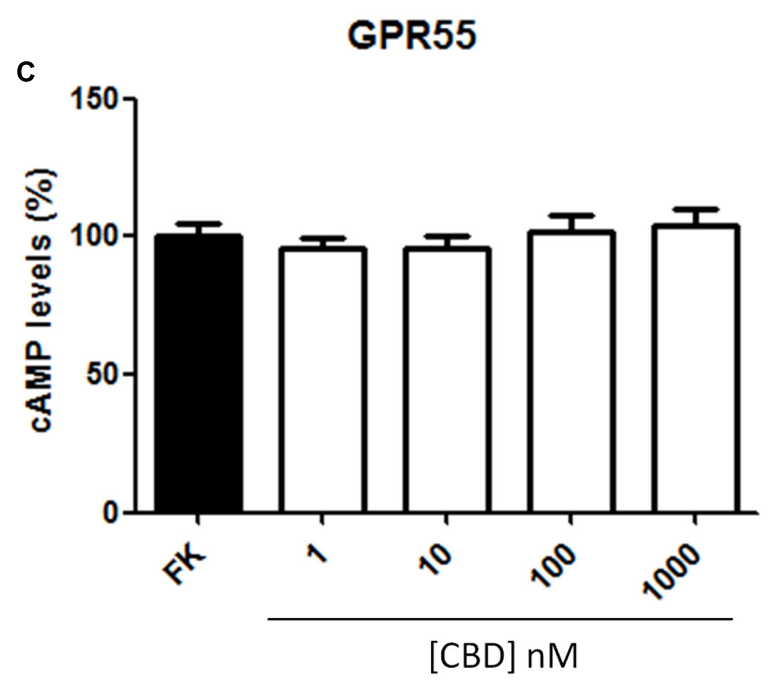

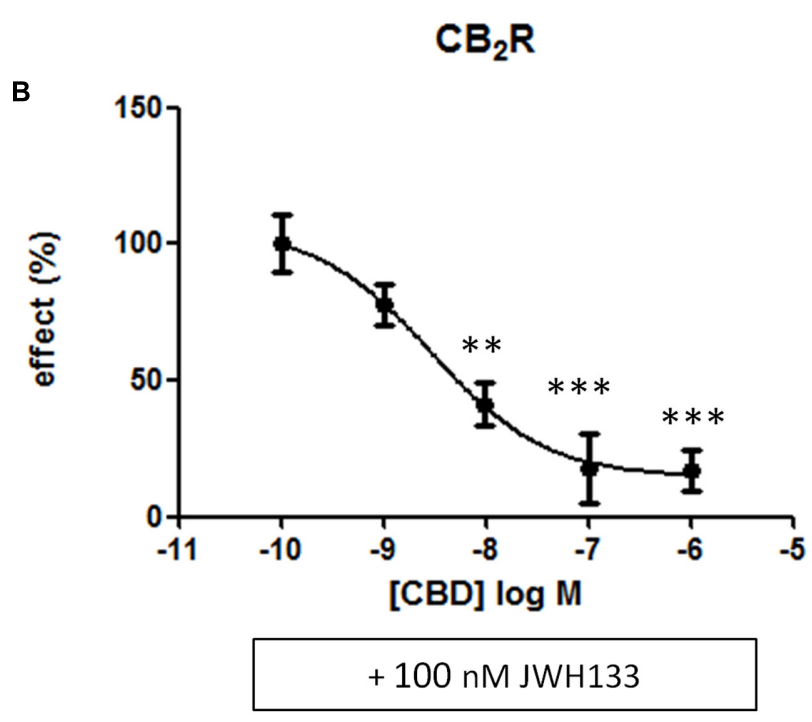

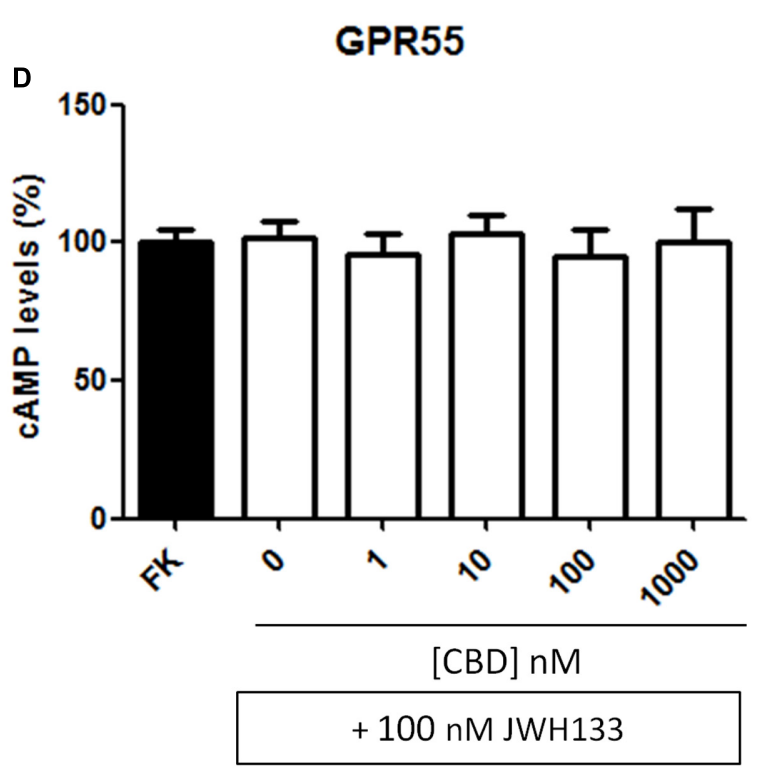

FIGURE 4 | Dose-response effect of CBD on cAMP levels. HEK-293T cells were transiently transfected with cDNA encoding for human CB 2 (A,B) or GPR55 (C,D) receptors. The effect of CBD on the decrease by JWH133 of forskolin-induced CAMP levels is displayed as a dose-response curve (B). Cells were treated (15 min) with different concentrations of CBD in the absence or presence of $100 \mathrm{nM} \mathrm{JWH133}$, a selective $\mathrm{CB}_{2} \mathrm{R}$ agonist and, finally, with $0.5 \mu \mathrm{M}$ forskolin (15 min). Agonist-induced reduction in CAMP was $31 \pm 4$ and data (mean \pm SEM) are given in percentage of the $500 \mathrm{nM}$ forskolin-induced cAMP concentration. Significant differences were analyzed on data from seven different experiments; one-way ANOVA and Bonferroni's multiple comparison post hoc test were used for statistical analysis $\left(F_{4,71}=15, p<0.001\right)\left({ }^{* *} p<0.01,{ }^{* * *} p<0.001\right.$, versus $0 \mathrm{nM}$ CBD treatment).

micromolar range $(4.2 \pm 0.3 \mu \mathrm{M})$. The same phenomenon was observed with increasing concentrations of THC, $K_{\mathrm{i}}$ value of $3.3 \pm 0.2 \mu \mathrm{M}$ (Figure 2A). Competition curves in radioligand binding assays were clearly monophasic, i.e., no significant effect was observed at submicromolar CBD concentrations.

Similar competition experiments were performed using $100 \mathrm{nM}$ of a fluorescent $\mathrm{CB}_{2} \mathrm{R}$ agonist and a recently described homogeneous non-radioactive method performed in living cells expressing the human version of the receptor (details in
Martínez-Pinilla et al., 2016). Competition of binding to the orthosteric center of the fluorescent agonist by CBD was partial but consistent, occurring at low nanomolar CBD concentrations (circa $25 \%$ reduction and $\mathrm{IC}_{50}$ in the $2-8 \mathrm{nM}$ range) (Figure $2 \mathrm{~B}$ ). In order to obtain more insight on the nature of $\mathrm{CBD}$ binding to $\mathrm{CB}_{2} \mathrm{R}$, saturation experiments were performed in HEK-293T cells expressing SNAP-CB $\mathrm{CB}_{2} \mathrm{R}$ and using increasing concentrations of red $\mathrm{CB}_{2} \mathrm{R}$ ligand in the presence of 10 or $100 \mathrm{nM}$ CBD. Data showed that CBD decreases the affinity of the orthosteric $\mathrm{CB}_{2} \mathrm{R}$ ligand, whereas maximum binding $\left(B_{\max }\right)$ 


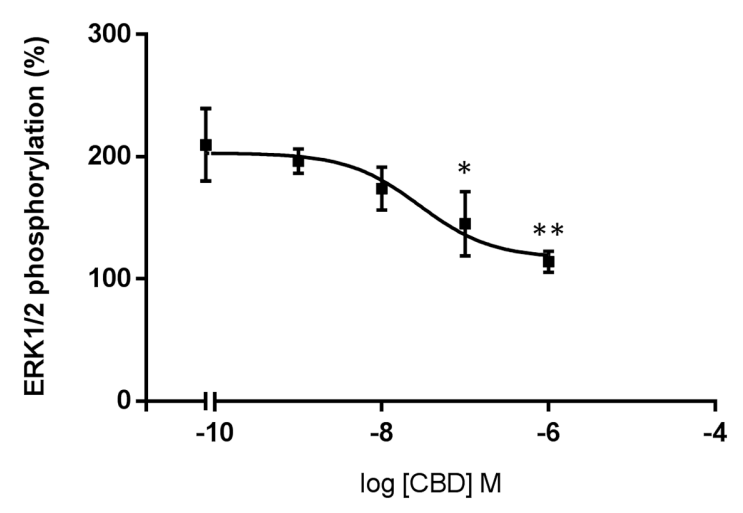

FIGURE 5 | Dose-response effect of CBD on ERK1/2 phosphorylation. HEK-293T cells transfected with human $\mathrm{CB}_{2} \mathrm{R}$ were stimulated with $100 \mathrm{nM}$ of JWH133 agonist in the presence of CBD. ERK1/2 phosphorylation levels were determined by using AlphaScreen ${ }^{\circledR}$ SureFire ${ }^{\circledR}$ kit. Data are normalized and expressed as a percentage of over-basal response (mean \pm SEM). Significant differences were analyzed on data from three different experiments; one-way ANOVA and Bonferroni's multiple comparison post hoc test were used for statistical analysis $\left(F_{4,10}=11, p<0.01\right)\left({ }^{*} p<0.05,{ }^{* *} p<0.01\right.$, versus $0 \mathrm{nM}$ CBD treatment).

was not modified (Figure $\mathbf{3 A}$ and Table $\mathbf{1}$ ). For comparison, a similar experiment was performed using 10 and $100 \mathrm{nM}$ concentrations of SR144528, a $\mathrm{CB}_{2} \mathrm{R}$ antagonist that reportedly binds to the orthosteric site (Rinaldi-Carmona et al., 1998; Griffin et al., 1999). The $K_{\mathrm{D}}$ value (Figure 3B) did not change when this selective $\mathrm{CB}_{2} \mathrm{R}$ antagonist was used. Interestingly, the antagonist reduced $B_{\max }$ values thus suggesting that it behaves, in binding to living cells, in an irreversible-like fashion. Taken together, the results were suggestive of CBD binding to an allosteric site at nanomolar concentrations while requiring higher concentrations (in the micromolar range) to bind to the orthosteric site.

\section{CBD Modulates $\mathrm{CB}_{\mathbf{2}} \mathrm{R}$ Signaling}

$\mathrm{CBD}$ action has been often associated to $\mathrm{CB}_{2} \mathrm{R}$ expression but its binding to the orthosteric site of the receptor is seemingly unspecific; we hypothesized that it might act as allosteric modulator. To test the hypothesis, we first confirmed that the compound (concentration range: 1-1,000 nM) did not significantly engage any G-protein-coupled signal in HEK-293T cells expressing the human version of $\mathrm{CB}_{2} \mathrm{R}$ (Figure $4 \mathrm{~A}$ ). $\mathrm{CBD}$ was also tested in cells expressing the human version of GPR55, a GPCR that may bind cannabinoids, and the results were similar to those in cells expressing the $\mathrm{CB}_{2} \mathrm{R}$ (Figure $4 \mathrm{C}$ ). We next tested whether CBD could affect the action of the selective $\mathrm{CB}_{2} \mathrm{R}$ agonist, JWH133, on forskolin-induced intracellular cAMP levels. The results show that the decrease in cAMP levels induced by $100 \mathrm{nM}$ JWH133 was dose-dependently blocked by CBD $\left(F_{4,71}=15, p<0.001\right)$ (Figure 4B). $\mathrm{IC}_{50}$ of the CBD effect was $3 \pm 0.4 \mathrm{nM}$. Again, the response of HEK-293T transiently transfected with GPR55 to the combined treatment with CBD and JWH133 was not significantly different than that achieved by CBD alone (Figure 4D). Similar experiments were undertaken but using ERK1/2 phosphorylation as a read-out. The results in Figure 5 show that significant ERK1/2 phosphorylation triggered by $100 \mathrm{nM}$ JWH133 was dose-dependently blocked by $\operatorname{CBD}\left(F_{4,10}=11, p<0.01\right)$ with an $\mathrm{IC}_{50}$ of $29 \pm 0.3 \mathrm{nM}$. These signaling data showed that CBD was able to negatively modulate $\mathrm{CB}_{2} \mathrm{R}$ signaling at concentrations lower to those required to significantly bind to the orthosteric center of the receptor.

\section{DISCUSSION}

The results reported confirm that nanomolar CBD concentrations are not able to displace the binding of WIN $55,212-2$ to the orthosteric center of the $\mathrm{CB}_{2} \mathrm{R}$ in radioligand binding assays. The binding data using the non-radioactive homogeneous method performed in living cells showed, however, that the binding of the fluorescent orthosteric ligand to HEK-293T cells expressing $\mathrm{CB}_{2} \mathrm{R}$ was slightly but consistently modified by nanomolar concentrations of CBD. The most plausible interpretation of these data is an allosteric effect disclosed in HTRF-mediated binding assays and a very small difference in the binding mode of radiolabeled WIN 55,212-2 or fluorescence-labeled CM-157 to $\mathrm{CB}_{2} \mathrm{R}$. Unfortunately, WIN $55,212-2$ could not be used in non-radioactive assays as it non-specifically interacted (for unknown reasons) with the HTRF probes. We found the same non-specific interaction with the fluorescent labeled CBD (data not shown). Structural differences related to the binding of different agonists that may be revealed by HTRF have been discussed elsewhere (Martínez-Pinilla et al., 2016). In that paper, the extensively studied ligand AM630 displayed a biphasic curve on competing with CM-157 binding to $\mathrm{CB}_{2} \mathrm{R}$. The results here presented could fit with CBD binding to the high-affinity sites disclosed using AM630 but not to the low-affinity ones. Alternatively, AM630 reduction of high-affinity binding, which occurred at subnanomolar concentrations of AM630, could be due to the same mechanism than that of CBD. In fact, the two compounds displayed on HTRF-based binding assays two components, one at low concentrations, and another at higher concentrations.

A further piece of information from results using the selective orthosteric $\mathrm{CB}_{2} \mathrm{R}$ antagonist, SR144528, was the irreversible-like behavior when performing HTRF-based binding to living cells. In binding or functional assays using isolated membranes or tissue extracts from $\mathrm{CB}_{2} \mathrm{R}$-expressing cells, the antagonist acts in a reversible fashion (Rinaldi-Carmona et al., 1998; Griffin et al., 1999). CBD seemingly allosteric action was detectable by functional experiments (cAMP and pERK1/2 assays) in which we show that the effect of a selective $C_{2} \mathrm{R}$ agonist was modulated by $\mathrm{CBD}$ at physiologically relevant (nanomolar) concentrations. The participation of a third component, acting as mediator of $\mathrm{CBD}$ effects on $\mathrm{CB}_{2} \mathrm{R}$ signaling cannot be ruled out.

In the absence of consensus data showing a direct interaction between $\mathrm{CBD}$ and cannabinoid receptors, only indirect evidence suggests that $\mathrm{CBD}$ could be a modulator of endocannabinoid 
signaling. Accordingly, CBD was suspected to act as allosteric modulator of cannabinoid receptors (Rimoldi and Bow, 2016). In agreement with this possibility, Laprairie et al. (2015) were the first to suggest that $\mathrm{CBD}$ acts as allosteric modulator of $\mathrm{CB}_{1} \mathrm{R}$; although no binding studies were performed, the allosteric site in the receptor was mapped to two cysteine residues in the $\mathrm{N}$-terminal end. Therefore, $\mathrm{CBD}$ reduces both potency and efficacy of endogenous and exogenous cannabinoids on ERK1/2-PLC $\beta 3$-dependent signaling in an heterologous expression system, and in cells endogenously expressing the receptor. Authors also reported that $\mathrm{CBD}$ affects the kinetics of $\beta$-arrestin recruitment and $\mathrm{CB}_{1} \mathrm{R}$ internalization.

Allosteric modulators of natural origin do usually provide negative modulation in both enzymology and pharmacology. Allosteric action was negative in both the results reported by Laprairie et al. (2015) on $\mathrm{CB}_{1} \mathrm{R}$-mediated signaling and ours on $\mathrm{CB}_{2} \mathrm{R}$-mediated signaling; the allosteric effect in both cases seems to be, at least in part, mediated by a CBD-induced decrease in affinity of the orthosteric agonist (Table 1). One interesting possibility would be that cannabinoids may produce effect of allosteric nature on a variety of GPCRs. In support of this option, Lane et al. (2010) showed that the endocannabinoid 2-AG acts as an allosteric modulator of the human adenosine $A_{3}$ receptor. Adenosine $A_{3}$ receptors are coupled to a heterotrimeric $G_{i}$ protein and the action of $2-A G$ resulted in a decrease in the potency of agonists and in the basal signaling of this adenosine receptor subtype. Their negative effects on the receptor-mediated cAMP response are similar to those reported here for $\mathrm{CBD}$ acting on $\mathrm{CB}_{2} \mathrm{R}$. $\mathrm{CBD}$ is also described as an allosteric modulator of $\mu$ - and $\partial$-opioid receptors (Vaysse et al., 1987; Kathmann et al., 2006). Both $\Delta^{9}$-THC and CBD accelerate the dissociation of opioids from the receptors although the function of CBD on opioid receptors was not studied (Kathmann et al., 2006).

Ligand-gated receptors are also affected by CBD. Indeed, $\mathrm{CBD}$ inhibits currents mediated by serotonin $5-\mathrm{HT}_{3 A}$ receptors expressed in Xenopus laevis oocytes (Yang et al., 2010). Higher $\mathrm{CBD}$ concentrations, in the micromolar range, are able to allosterically modulate ligand-gated glycine receptors impacting on the role of glycine in postsynaptic transmission in the adult spinal cord (Ahrens et al., 2009; Foadi et al., 2010). The interacting motif is mapped to $\operatorname{Ser}^{276}$ of the alphal subunit of the receptor (Foadi et al., 2010), thus seemingly different from the binding motif reported for $\mathrm{CB}_{1} \mathrm{R}$ (Laprairie et al., 2015). Homologous residues to those in the $C_{1} R$ sequence are not present in the $\mathrm{CB}_{2} \mathrm{R}$ one and, therefore, the putative binding site may not be located in the $\mathrm{N}$-terminal domain of the $\mathrm{CB}_{2} \mathrm{R}$; in fact, the putative $\mathrm{N}$-terminal domain is much shorter for $\mathrm{CB}_{2}$ than for $\mathrm{CB}_{1}$ receptors (33 versus 116 amino acids ${ }^{2}$ ). Elucidation of the structure for the $\mathrm{CB}_{1} \mathrm{R}$ rises hope for a similar achievement for $\mathrm{CB}_{2} \mathrm{R}$ and, subsequently, for detecting allosteric sites that would help in designing novel drug discovery approaches targeting cannabinoid receptors. The $\mathrm{N}$-terminal domain of the $\mathrm{A}_{3}$ receptor is also too short to

${ }^{2}$ www.uniprot.org be involved in the mode of action of 2-AG. Human $\mu$ and $\partial$ opioid receptors have longer N-terminal domains, 68 and 47 , respectively, but there is no obvious homology between them. The two cysteine residues present in the N-terminal end of $\mathrm{CB}_{1} \mathrm{R}$ and that putatively conform a $\mathrm{CBD}$ binding site are not present in the $\mathrm{N}$-terminal domain of $\partial$-opioid receptors. In summary, further experimental effort is needed to identify common motives for endocannabinoid action on ligand-gated and GPCRs, or to identify molecules interacting with these receptors and acting as mediators of the allostericlike effect disclosed by CBD. Finding CBD binding motives in cannabinoid receptors or non-GPCR CBD targets would help in understanding some of the actions reported for endocannabinoids and for natural cannabinoids such as THC and CBD.

GPCRs constitute the target of $40-45 \%$ of current medicines that act, as agonists or antagonists, via the orthosteric center. The discovery of GPCR allosteric modulators or of modulators of signaling at concentrations 1-2 orders of magnitude below the $\mathrm{IC}_{50}$ values obtained in competing with the binding of orthosteric compounds, opens new perspectives for therapeutic benefit.

\section{AUTHOR CONTRIBUTIONS}

EM-P designed and executed HTRF experiments, analyzed HTRF data, and edited the manuscript; IR-R, EA, and GN cloned the fusion proteins and performed HTRF and cAMP assays; JL directed the pharmacological assays in CIMA and contributed to scientific discussions and editing the manuscript. JO participated in the design and the synthesis of labeled compounds for HTRF assays. EC contributed to the analysis of results. CF-V and XN contributed to the conception and design of the study and were implied in the process of writing the manuscript, the analysis and interpretation of data, and critically reviewed and approved the manuscript; KV and FV designed and supervised the radioligand binding experiments and contributed to manuscript edition; $\mathrm{KV}$ and $\mathrm{PB}$ performed the radioligand binding assays; RF contributed in formulating the initial hypothesis, directed the work in the University of Barcelona (Barcelona), coordinated efforts from different laboratories, and participated in writing the manuscript.

\section{FUNDING}

This research was supported by the SAF2012/39875-C02-01 grant from Spanish Ministry of Economy and Innovation, and by grants 201413330 and 201441331 from Fundació La Marató de TV3.

\section{SUPPLEMENTARY MATERIAL}

The Supplementary Material for this article can be found online at: https://www.frontiersin.org/articles/10.3389/fphar.2017. 00744/full\#supplementary-material 


\section{REFERENCES}

Ahrens, J., Demir, R., Leuwer, M., de la Roche, J., Krampfl, K., Foadi, N., et al. (2009). The nonpsychotropic cannabinoid cannabidiol modulates and directly activates alpha-1 and alpha-1-Beta glycine receptor function. Pharmacology 83, 217-222. doi: 10.1159/000201556

Alvarez, F. J., Lafuente, H., Carmen Rey-Santano, M., Mielgo, V. E., Gastiasoro, E., Rueda, M., et al. (2008). Neuroprotective effects of the nonpsychoactive cannabinoid cannabidiol in hypoxic-ischemic newborn piglets. Pediatr. Res. 64, 653-658. doi: 10.1203/PDR.0b013e318186e5dd

Alves, F. H. F., Crestani, C. C., Gomes, F. V., Guimarães, F. S., Correa, F. M. A., and Resstel, L. B. M. (2010). Cannabidiol injected into the bed nucleus of the stria terminalis modulates baroreflex activity through 5-HT1A receptors. Pharmacol. Res. 62, 228-236. doi: 10.1016/j.phrs.2010.05.003

Bilkei-Gorzo, A. (2012). The endocannabinoid system in normal and pathological brain ageing. Philos. Trans. R. Soc. B Biol. Sci. 367, 3326-3341. doi: 10.1098/rstb. 2011.0388

Cabral, G. A., and Marciano-Cabral, F. (2005). Cannabinoid receptors in microglia of the central nervous system: immune functional relevance. J. Leukoc. Biol. 78, 1192-1197. doi: 10.1189/jlb.0405216

Callén, L., Moreno, E., Barroso-Chinea, P., Moreno-Delgado, D., Cortés, A., Mallol, J., et al. (2012). Cannabinoid receptors CB1 and CB2 form functional heteromers in brain. J. Biol. Chem. 287, 20851-20865. doi: 10.1074/jbc.M111. 335273

Castillo, C. A., Albasanz, J. L., Fernández, M., and Martín, M. (2007). Endogenous expression of adenosine A1, A2 and A3 receptors in rat C6 glioma cells. Neurochem. Res. 32, 1056-1070. doi: 10.1007/s11064-006-9273-x

Cheng, H. C. (2001). The power issue: determination of KB or Ki from IC50. A closer look at the Cheng-Prusoff equation, the Schild plot and related power equations. J. Pharmacol. Toxicol. Methods 46, 61-71. doi: 10.1016/S10568719(02)00166-1

Conn, P. J., Christopoulos, A., and Lindsley, C. W. (2009). Allosteric modulators of GPCRs: a novel approach for the treatment of CNS disorders. Nat. Rev. Drug Discov. 8, 41-54. doi: 10.1038/nrd2760

Espejo-Porras, F., Fernández-Ruiz, J., Pertwee, R. G., Mechoulam, R., and García, C. (2013). Motor effects of the non-psychotropic phytocannabinoid cannabidiol that are mediated by 5 -HT1A receptors. Neuropharmacology 75 , 155-163. doi: 10.1016/j.neuropharm.2013.07.024

Fernández-Ruiz, J., Romero, J., Velasco, G., Tolón, R. M., Ramos, J. A., and Guzmán, M. (2007). Cannabinoid CB2 receptor: a new target for controlling neural cell survival? Trends Pharmacol. Sci. 28, 39-45. doi: 10.1016/j.tips.2006. 11.001

Foadi, N., Leuwer, M., Demir, R., Dengler, R., Buchholz, V., de la Roche, J., et al. (2010). Lack of positive allosteric modulation of mutated alpha(1)S267I glycine receptors by cannabinoids. Naunyn. Schmiedebergs. Arch. Pharmacol. 381, 477-482. doi: 10.1007/s00210-010-0506-9

Griffin, G., Wray, E. J., Tao, Q., McAllister, S. D., Rorrer, W. K., Aung, M. M., et al. (1999). Evaluation of the cannabinoid CB2 receptor-selective antagonist, SR144528: further evidence for cannabinoid CB2 receptor absence in the rat central nervous system. Eur. J. Pharmacol. 377, 117-125. doi: 10.1016/S00142999(99)00402-1

Hanus, L., Tchilibon, S., Ponde, D. E., Breuer, A., Fride, E., and Mechoulam, R. (2005). Enantiomeric cannabidiol derivatives: synthesis and binding to cannabinoid receptors. Org. Biomol. Chem. 3, 1116-1123. doi: 10.1039/ b416943c

Hind, W. H., England, T. J., and O’Sullivan, S. E. (2016). Cannabidiol protects an in vitro model of the blood-brain barrier from oxygen-glucose deprivation via PPAR $\gamma$ and 5-HT 1A receptors. Br. J. Pharmacol. 173, 815-825. doi: 10.1111/ bph. 13368

Ignatowska-Jankowska, B., Jankowski, M. M., and Swiergiel, A. H. (2011). Cannabidiol decreases body weight gain in rats: involvement of $\mathrm{CB} 2$ receptors. Neurosci. Lett. 490, 82-84. doi: 10.1016/j.neulet.2010.12.031

Kathmann, M., Flau, K., Redmer, A., Tränkle, C., and Schlicker, E. (2006). Cannabidiol is an allosteric modulator at mu- and delta-opioid receptors. Naunyn Schmiedebergs Arch. Pharmacol. 372, 354-361. doi: 10.1007/s00210006-0033-x

Lafuente, H., Alvarez, F. J., Pazos, M. R., Alvarez, A., Rey-Santano, M. C., Mielgo, V., et al. (2011). Cannabidiol reduces brain damage and improves functional recovery after acute hypoxia-ischemia in newborn pigs. Pediatr. Res. 70, 272-277. doi: 10.1203/PDR.0b013e3182276b11

Lanciego, J. L., Barroso-Chinea, P., Rico, A. J., Conte-Perales, L., Callén, L., Roda, E., et al. (2011). Expression of the mRNA coding the cannabinoid receptor 2 in the pallidal complex of Macaca fascicularis. J. Psychopharmacol. 25, 97-104. doi: 10.1177/0269881110367732

Lane, J. R., Beukers, M. W., Mulder-Krieger, T., and IJzerman, A. P. (2010). The endocannabinoid 2-arachidonylglycerol is a negative allosteric modulator of the human A3 adenosine receptor. Biochem. Pharmacol. 79, 48-56. doi: 10.1016/j. bcp.2009.07.024

Laprairie, R. B., Bagher, A. M., Kelly, M. E. M., and Denovan-Wright, E. M. (2015). Cannabidiol is a negative allosteric modulator of the cannabinoid CB1 receptor. Br. J. Pharmacol. 172, 4790-4805. doi: 10.1111/bph.13250

$\mathrm{Lu}, \mathrm{H}$. C., and MacKie, K. (2016). An introduction to the endogenous cannabinoid system. Biol. Psychiatry 79, 516-525. doi: 10.1016/j.biopsych.2015.07.028

Magen, I., Avraham, Y., Ackerman, Z., Vorobiev, L., Mechoulam, R., and Berry, E. M. (2010). Cannabidiol ameliorates cognitive and motor impairments in bile-duct ligated mice via 5-HT 1A receptor activation. Br. J. Pharmacol. 159, 950-957. doi: 10.1111/j.1476-5381.2009.00589.x

Martínez-Pinilla, E., Rabal, O., Reyes-Resina, I., Zamarbide, M., Navarro, G., Sánchez-Arias, J. A., et al. (2016). Two affinity sites of the cannabinoid subtype 2 receptor identified by a novel homogeneous binding assay. J. Pharmacol. Exp. Ther. 358, 580-587. doi: 10.1124/jpet.116.234948

McPartland, J. M., Duncan, M., Di Marzo, V., and Pertwee, R. G. (2015). Are cannabidiol and $\Delta 9$-tetrahydrocannabivarin negative modulators of the endocannabinoid system? A systematic review. Br. J. Pharmacol. 172, 737-753. doi: 10.1111/bph.12944

McPartland, J. M., Glass, M., and Pertwee, R. G. (2009). Meta-analysis of cannabinoid ligand binding affinity and receptor distribution: interspecies differences. Br. J. Pharmacol. 152, 583-593. doi: 10.1038/sj.bjp.0707399

Morales, P., Goya, P., Jagerovic, N., and Hernandez-Folgado, L. (2016). Allosteric modulators of the CB 1 cannabinoid receptor?: a structural update review. Cannabis Cannabinoid Res. 1, 22-30. doi: 10.1089/can.2015.0005

Pamplona, F. A., Ferreira, J., Menezes de Lima, O., Duarte, F. S., Bento, A. F., Forner, S., et al. (2012). Anti-inflammatory lipoxin A4 is an endogenous allosteric enhancer of CB1 cannabinoid receptor. Proc. Natl. Acad. Sci. U.S.A. 109, 21134-21139. doi: 10.1073/pnas. 1202906109

Pazos, M. R., Mohammed, N., Lafuente, H., Santos, M., Martínez-Pinilla, E., Moreno, E., et al. (2013). Mechanisms of cannabidiol neuroprotection in hypoxic-ischemic newborn pigs: role of 5HT1A and CB2 receptors. Neuropharmacology 71, 282-291. doi: 10.1016/j.neuropharm.2013.03.027

Pertwee, R. G. (2008). The diverse CB 1 and CB 2 receptor pharmacology of three plant cannabinoids: $\Delta 9$-tetrahydrocannabinol, cannabidiol and $\Delta 9$ -tetrahydrocannabivarin. Br. J. Pharmacol. 153, 199-215. doi: 10.1038/sj.bjp. 0707442

Rimoldi, J., and Bow, E. (2016). The structure-function relationships of classical cannabinoids: CB1/CB2 modulation. Perspect. Medicin. Chem. 8, 17-39. doi: 10.4137/PMC.S32171

Rinaldi-Carmona, M., Barth, F., Millan, J., Derocq, J. M., Casellas, P., Congy, C., et al. (1998). SR 144528, the first potent and selective antagonist of the CB2 cannabinoid receptor. J. Pharmacol. Exp. Ther. 284, 644-650.

Rock, E., Bolognini, D., Limebeer, C., Cascio, M., Anavi-Goffer, S., Fletcher, P., et al. (2012). Cannabidiol, a non-psychotropic component of cannabis, attenuates vomiting and nausea-like behaviour via indirect agonism of 5-HT1A somatodendritic autoreceptors in the dorsal raphe nucleus. Br. J. Pharmacol. 165, 2620-2634. doi: 10.1111/j.1476-5381.2011.01621.x

Russo, E. B., Burnett, A., Hall, B., and Parker, K. K. (2005). Agonistic properties of cannabidiol at 5-HT1a receptors. Neurochem. Res. 30, 1037-1043. doi: 10.1007/ s11064-005-6978-1

Sartim, A. G., Guimarães, F. S., and Joca, S. R. L. (2016). Antidepressant-like effect of cannabidiol injection into the ventral medial prefrontal cortex-Possible involvement of 5-HT1A and CB1 receptors. Behav. Brain Res. 303, 218-227. doi: 10.1016/j.bbr.2016.01.033

Sierra, S., Luquin, N., Rico, A. J., Gómez-Bautista, V., Roda, E., Dopeso-Reyes, I. G., et al. (2015). Detection of cannabinoid receptors CB1 and CB2 within basal ganglia output neurons in macaques: changes following experimental parkinsonism. Brain Struct. Funct. 220, 2721-2738. doi: 10.1007/s00429-0140823-8 
Stella, N. (2010). Endocannabinoid signaling in microglial cells. Glia 58(Suppl. 1), 244-253. doi: 10.1002/glia.20983

Thomas, A., Baillie, G. L., Phillips, A. M., Razdan, R. K., Ross, R. A., and Pertwee, R. G. (2009). Cannabidiol displays unexpectedly high potency as an antagonist of CB1 and CB2 receptor agonists in vitro. Br. J. Pharmacol. 150, 613-623. doi: 10.1038/sj.bjp.0707133

Vaysse, P. J., Gardner, E. L., and Zukin, R. S. (1987). Modulation of rat brain opioid receptors by cannabinoids. J. Pharmacol. Exp. Ther. 241, 534-539.

Verbist, B. M. P., De Cleyn, M. A. J., Surkyn, M., Fraiponts, E., Aerssens, J., Nijsen, M. J. M. A., et al. (2008). 5-Sulfonyl-benzimidazoles as selective CB2 agonists. Bioorg. Med. Chem. Lett. 18, 2574-2579. doi: 10.1016/j.bmcl.2008. 03.048

Yang, K.-H., Galadari, S., Isaev, D., Petroianu, G., Shippenberg, T. S., and Oz, M. (2010). The nonpsychoactive cannabinoid cannabidiol inhibits 5-hydroxytryptamine3A receptor-mediated currents in Xenopus laevis oocytes. J. Pharmacol. Exp. Ther. 333, 547-554. doi: 10.1124/jpet.109. 162594
Zhang, J., Hoffert, C., Vu, H. K., Groblewski, T., Ahmad, S., and O'Donnell, D. (2003). Induction of CB2 receptor expression in the rat spinal cord of neuropathic but not inflammatory chronic pain models. Eur. J. Neurosci. 17, 2750-2754. doi: 10.1046/j.1460-9568.2003.02704.x

Conflict of Interest Statement: The authors declare that the research was conducted in the absence of any commercial or financial relationships that could be construed as a potential conflict of interest.

Copyright (c) 2017 Martínez-Pinilla, Varani, Reyes-Resina, Angelats, Vincenzi, Ferreiro-Vera, Oyarzabal, Canela, Lanciego, Nadal, Navarro, Borea and Franco. This is an open-access article distributed under the terms of the Creative Commons Attribution License (CC BY). The use, distribution or reproduction in other forums is permitted, provided the original author(s) or licensor are credited and that the original publication in this journal is cited, in accordance with accepted academic practice. No use, distribution or reproduction is permitted which does not comply with these terms. 